\title{
COMMENTS
}

\section{FEDERAL ESTATE TAX: JOINT WILLS AND THE MARITAL DEDUGTION}

Estate planners generally attempt to employ methods of property disposition that accomplish their clients' wishes at the lowest possible tax cost. Several recent decisions indicate that one means of handling a married couple's estate, a contractual joint and mutual will, ${ }^{1}$ may have significant tax advantages. However, a close analysis of the federal tax statute and the body of case law relating to such wills casts doubt on the propriety of too ready an acceptance of these cases by the practitioner.

\section{The Marital Deduction}

In computing the amount of the net estate, section 2056 (a) of the Internal Revenue Code allows a deduction of up to fifty per cent of the adjusted gross estate ${ }^{2}$ for the value of any property inter-

${ }^{1} \mathrm{~A}$ joint will is a single testamentary document containing the wills of two or more testators. Mutual wills are the separate wills (not necessarily separate documents) or two or more testators, who have drafted such wills pursuant to a common testamentary scheme and made reciprocal provisions for each other. See, e.g., Danicls v. Bridges, 123 Cal. App. 2d 585, 267 P.2d 343 (Dist. Ct. App. 1954). Mutual wills have also been defined as testaments executed in accord with an agreement between the testators not to revoke the will. Campbell v. Dunkelberger, 172 Iowa 385, 389, 153 N.W. 56, 58 (1915). There is much terminological confusion among the courts in describing such wills and the terms arc often interchanged. The terms "double" and "conjoint" are sometimes used to create further dubious distinctions. See gencral. ly 97 C.J.S. Wills $\S 1364$ and cases cited therein.

In many cases involving such wills, it is found that they have been executed pursuant to an agreement not to revoke the will after the death of a participating testator. The contract may be expressly recited in the will or implied from the relationship of the testators and the circumstances. See, e.g., Thompson v. Boyd, 217 Cal. App. 2d 405, 32 Cal. Rptr. 513 (Dist. Ct. App. 1963); Frazier v. Patterson, 243 I11. 80,90 N.E. 216 (1909). The nature and incidents of such contracts have been frequently discussed. See generally Eagleton, Joint and Mutual Wills: Mutual Promises to Devise as a Means of Conveyancing, 15 CoRnell L.Q. 358 (1930); Notc, Joint and Mutual Wills, 61 HARv. L. Rev. 675 (1948); Annot., 169 A.L.R. 9 (1947); text accompanying notes 21-31 infra.

In general, use of the term "joint will" in this comment presupposes that the document is executed pursuant to a contract depriving the survivor of the right to revoke the will or make an inconsistent disposition of the property subject to the terms of the will and the contract. The ideas presented are just as valid for scparate mutual wills executed pursuant to such a contract.

${ }^{2}$ INT. REV. CODE OF 1954, $\$ 2056$ (c) (1). A similar limitation was contained in INT. REv. CoDe of 1939, $\S 812(e)(1)(H)$, added by ch. 168, 62 Stat. 119 (1948). The 50\% limitation is intended to correspond to the interest that a surviving spouse in a 
est passing from the decedent to his surviving spouse. ${ }^{3}$ To qualify for this deduction, the interest must be "non-terminable." Essentially, this means that the interest must not be so limited as to fail on the happening of some contingency such as the survivor's death or remarriage.4 Even "terminable" interests will qualify for the deduction, however, if no third person has received a future interest in the same property from the decedent.5 Section 2056 (b) (5) authorizes the deduction where the interest acquired by the surviving spouse is equivalent to a life estate coupled with a general power to appoint intervivos or by will. ${ }^{6}$ This type of interest, however, will

community property jurisdiction would acquire by law during the marriage. The adjusted gross estate is a concept devised particularly for determiuing the amount of the marital deduction. Generally speaking, it is calculated by subtracting from the gross estate certain of the estate's expenses and the value of any community property share in the decedent's estate. See INT. REv. CoDE of 1954, § 2056(c)(2); S. REP. No. 1013, 80th Cong., 2d Sess., pt. I, at 5 (1948).

INT. REv. CODE OF 1954, $\$ 2056$ (a). A similar provision was contained in Iut. Rev. Code of $1999, \S 812(e)(1)(A)$, added by ch. 168, 62 Stat. 117 (1948).

INT. REv. Code of 1954, $\$ 2056$ (b) (I). A similar provision was contained in Int. Rev. Code of 1939, $\S 812(\mathrm{e})(\mathrm{I})(\mathrm{B})$, added by ch. 168, 62 Stat. 117. (1948).

Two recent cases interpreting "terminability" are Jackson v. United States, 32 U.S.L. WEER 4222 (U.S. March 23, 1964) aud United States v. Mappes, 318 F.2d 508 (10th Cir. 1963). The Court in the Jackson case held that a court order giving the surviving widow a fixed allowance over a twenty-four month period would not qualify the money set aside for such allowance for the deduction. The terminability of the widow's interest arose from the fact that her right to the money ceased upon her death or remarriage within the designated period. In the Mappes case, the widow was to receive the residue of the estate only if she survived the estate's distribution. The court held that her interest was terminable since the coutingency of her surviving the distribution might not occur and her interest would thereby fail. See generally Lowndes \& Kramer, Federal Estate and Gift Taxation 384-94 (2d ed. 1962) [hereinafter cited as LownDEs \& KRAMER].

- INT. Rev. CoDE of 1954, \$\$ 2056(b)(1)(A), (B), (e)(1)-(7).

INT. Rev. CoDe of 1954, $\$ 2056(\mathrm{~b})(5)$. The language in the Code is broad enough to include both legal life estates coupled with an absolute power of appointment and interests held in trust for a surviving spouse duriug his lifetime, such spouse being able to invade the corpus of the trust. Under the 1939 Code, the deduction was allowed only if the interest were held in trust for the survivor. Int. Rev. Code of $1939, \S 812(\mathrm{e})(\mathrm{I})(\mathrm{F})$, added by ch. 168, 62 Stat. 118 (1948). The Technical Changes Act of 1958 extended the provisions of the 1954 Code retroactively, allowiug the deduction to such life estates to the estates of all decedents dying after April I, 1948. 72 Stat. 1606 (1958).

In Thomas v. United States, 317 F.2d 519 (6th Cir. 1963), the trustee, who held a residence in trust for the widow, was given the power and discretion to sell the trust res and apply the proceeds to the support of both the widow and the decedent's sons. The Court of Appeals held that the widow did not receive an adequate life estate and power to qualify for the deduction because of the additional discretionary power put in the trustee. In Piatt v. Gray, 321 F.2d 79 (6th Cir. 1963), where the widow's power of appoiutment could be exercised only for her comfort aud well being, the court refused to qualify the interest for the deduction since the power would not be exercisable in all events. See generally Lowndes \& KRAMER 407-10; Treas. Reg. $\$ 20.2056$ (b) -5 (1954). 
not qualify for the deduction if any third person has the right or duty to interfere with the spouse's exercise of the power. ${ }^{7}$ The value of this type of interest to the surviving spouse resembles that of a fee simple which would qualify under section 2056 (a) of the Code. ${ }^{8}$

\section{Tax Gases Involving Joint Wills}

- The contractual features found in many joint and mutual wills create some special problems in determining the nature of the survivor's interest for the purposes of the marital deduction. ${ }^{0}$ While the surviving testator technically might be viewed as acquiring a fee simple interest in the decedent's property if the joint will so specifies, ${ }^{10}$ contractual obligations are often imposed on the survivor and

T The interest will be allowed in this situation "only if [the] . . . power in the surviving spouse to appoint the . . . interest . . . is exercisable by such spotise alone and in all events." INT. REv. CoDE of 1954, § 2056(b)(5).

8 The similarity in the two types of interests is derived from the surviving spouse's ultimate control over the eventual disposition of the property involved. Section 2056 (b)(1) disallows the deduction if interests in the same property have passed from the decedent to third persons as well as the surviving spouse. Section $2056(\mathrm{~b})(5)$ allows third persons to receive those interests if such interests are subject completely to the surviving spouse's whims and desires.

Another similarity lies in the includibility of both types of interests in the surviving spouse's estate. S. REP. No. 1013, 80th Cong. 2d Sess., pt. II, at 3 (1948). The absolute fce simple interest eligible for the deduction under $\S 2056(\mathrm{~b})(1)$ would naturally be in the survivor's estate; the value of property subject to such a power as required by $\S 2056(\mathrm{~b})(5)$ is also included. INT. Rev. Cone of 1954, $\$ 2041(\mathrm{~b})(1)$. The marital deduction is thus limited to interests that normally would be included in the survivor's estate unless consumed or dissipated prior to the survivor's death. One object of the deduction is to prevent property from being subject to the estate tax twice within one generation, not to allow it to escape such taxation altogether. United States v. Stapf, 375 U.S. 118, 128 (1963).

- Very few courts have tried to analyze the actual interests received by the surviving testator in a joint will situation, but instead have concentrated upon the enforcement of whatever contract may underlie the will. Often a joint will may specify that the survivor is to receive all of the property of the first testator to die, but a contract inherent in the will would keep such survivor from treating the property as if he had a fee simple absolute in it. See, e.g., Jennings v. McKeen, 245 Iowa 1206, 65 N.W.2d 207 (1954). For a survey of the contractual restrictions put upon the surviving testator, see text at notes 21-30 infra.

In one recent case, the Iowa court turned down the opportunity to define the technical legal interest held by the survivor in property formerly held in joint tenancy by the survivor and the decedent. Tiemann v. Kampmeier, 252 Iowa 587, 107 N.W.2d 689 (1961). What actually happened was termed "immaterial"; the survivor was viewed as holding the property "in the nature of a trust, subject to a life cstate, for the beneficiaries named in ... the will." 107 N.W.2d at 692.

${ }^{10}$ The joint will in Nettz v. Phillips, 202 F. Supp. 270 (S.D. Iowa 1962), discussed at note 16 infra, provided that the survivor should receive the property absolutely and in fee simple. Such a provision seems to clash with the contract not to revoke the will or render it inoperative, which was also recited in the Nettz will. $202 \mathrm{~F}$. Supp. at 271. While a court might be compelled to hold that the survivor in the Nettz case received the legal title in fee simple, there is no reason why the analysis 
result in restrictions upon his ability to deal freely with the property. ${ }^{11}$ However, the leading case and several of its successors, in determining the effect of such an instrument on the allowance of the marital deduction, seem to establish that these contractual elements will not disqualify the interest.

In Estate of Awtry v. Commissioner ${ }^{12}$ the Eighth Circuit reversed a Tax Court decision disallowing the deduction on the ground that the joint will, in effect, had created a life estate in the surviving widow with remainders over to others. ${ }^{13}$ The property involved had been held by the spouses as joint tenants with the husband supplying the consideration for its purchase. The circuit court held that the wife had taken the legal fee in the property by right of survivor. ship. This, coupled with the fact that any restrictions on the use of the property created by the applicable state law relating to joint wills had been voluntarily incurred by the widow, was held sufficient to render her interest "non-terminable" and hence deductible. The Awtry case was recently followed in McLean v. United States ${ }^{14}$ as to property held by the decedent and surviving spouse as tenants by the entireties. The district court rejected the Government's contention that the joint will somehow "changed the form of ownership of the property." 15 Since any restriction placed upon the survivor by state law was derived from the underlying contract and not from the will itself, the survivor was held to have received the absolute legal title to the property. The court did not consider the status of the decedent's separate property which passed under the will since the value of the property held jointly or by the entireties exceeded one-half of the adjusted gross estate, the maximum allowable deduction.

However, two recent district court decisions seem to extend the Awtry approach to cases involving the decedent's separate property. The courts allowed the interests in such property passing to the sur-

\footnotetext{
of Tiemann v. Kampmeier, supra note 9, would not be applicable. However, the fact that technical terms such as "fee simple" were used might help the court ascertain exactly what the agreement between the parties was. It could indicate that the survivor was to have an uncontrolled power of disposition over the property during his lifetime, as the court in fact decided. 202 F. Supp. at 272.

11 See text accompanying notes 21-31 infra.

19 221 F.2d 749 (8th Cir. 1955).

${ }^{13}$ Estate of Emmet Awtry, 22 T.C. 91 (1954).

14 224 F. Supp. 726 (E.D. Mich. 1963).

${ }^{15}$ Id. at 729 . See note 35 infra.
} 
viving spouses under the joint will to qualify for the deduction. The interests so received were viewed as the equivalents of life estates coupled with an adequate power of appointment. In Nettz .v. Phillips, ${ }^{16}$ the terms of the joint will stipulated that the survivor was to receive the property "absolutely and in fee simple," but a contract between the spouses not to revoke or render inoperative the provisions of the will was also recited in the will's first paragraph. The court determined that, under the applicable state law, no restrictions had been placed on the survivor's right to dispose of the property during his lifetime that would affect the estate's right to claim the deduction. ${ }^{17}$ In Spicer $v$. United States ${ }^{18}$ a similar will contained in its preamble a recitation of a contract that deprived the survivor of any power to make "a different disposition of the property passing under this Will." 19 The interest acquired by the suryiving spouse consisted both of the decedent's separate property and some realty formerly held by the decedent and spouse as joint tenants. Despite the apparent restriction on the survivor's right to deal freely with the property during the period of survivorship, the court held that the interest in both the separately and jointly held property qualified for the deduction by interpreting the probate court's decree as granting the widow "a life estate . . . with an unrestricted right and power of disposition."20

\section{The Survivor's INTEREST UNDER A JoINT WILL}

Once a contract underlying a joint will has become binding on the surviving testator, ${ }^{21}$ he does not have the power to give away or

${ }^{16} 202$ F. Supp. 270 (S.D. Iowa 1962).

${ }^{17}$ See note 47 infra.

${ }^{18} 217$ F. Supp. 44 (D. Kan. 1963).

10 Id. at 46.

so 217 F. Supp. at 53. The probate court's decree recited "That Maude E. Spicer, his widow, is entitied to have and receive all the rent and residue of said estatc . . . subject to the provision that any property or investments, in whatever form as may remain at the death of Maude E. Spicer, shall go and pass to * * [the five children]." (Emphasis supphed by the district court). Ibid.

21 The contract which underlies a joint or mutual will may not be inferred, in most jurisdictions, from the mere execution of a joint will or a simultancous exccution of mutual wills. See, e.g., Father Flanagan's Boys' Home v. Turpin, 252 Iowa 603, 106 N.W.2d 637 (1961). Sce generally SPARKs, Contracts to MAKE Wills 24, 25 (1956); Annot., 169 A.L.R. 9 (1947); note infra. Many older cases assume that a joint will could not possibly be executed unless it were done pursuant to an agrecment. See, e.g., Frazier v. Patterson, 243 Ill. 80, 90 N.E. 216 (1909); Doyle v. Fischer 183 Wis. 599,198 N.W. 763 (1924). A conclusive inference of a contract from the mere execution of a joint will is apparently still the law in Wisconsin. Olson v. Reisimer, $271 \mathrm{~F} .2 \mathrm{~d} 623$ (7th Cir. 1959). If the wording of the will contains contractual 
otherwise deal with the property in a manner that defeats the ultimate distributive plan contained in the will. ${ }^{22}$ The remedy for the beneficiaries of such a joint will is a legal or equitable action based upon the contract. ${ }^{23}$

Any attempt by a survivor to revoke the joint will by executing a new and separate testament can be effectively nullified after the survivor's death. In most jurisdictions, the contractual beneficiaries will not be permitted to obtain direct relief by having the revoked joint will admitted to probate as the last will of the survivor. ${ }^{24}$

language or refers to or recites an agreement or contract between the testators, it would seem unquestionable that a contract has been established. Tontz v. Heath, 20 Ill. 2d 286, 291-92, 170 N.E.2d 153, 156-57 (1960); In the Matter of Estate of Logan, 253 Iowa 1211, 115 N.W.2d 701 (1962). If the will does not incorporate the contract, such an agreement must be proved by "clear," "cogent," and "compelling" evidence. Tontz v. Heath, supra (clear, convincing, and satisfactory); Oursler v. Armstrong, 10 N.Y.2d 385, 389, 179 N.E.2d 489, 491, 223 N.Y.S.2d 477, 479 (1961) (clear). However, the mere execution of a joint will or mutual wills may be sufficient part performance to remove any Statute of Frauds objection to parol proof of the contract. Curry v. Cotton, 356 Ill. 538, 191 N.E. 307 (1934); Kirk v. Beard, 162 Tex. 144, 345 S.W.2d 267 (1961); Note, Joint or Mutual Wills,61 HARv. L. Rev. 675, 681 (1948).

${ }^{23}$ See, e.g., Tontz v. Heath, supra note 21 (intervivos transfers by a surviving wife set aside where the conveyances acted to defeat the contract embodied in the will); Rich v. Mottek, 11 N.Y.2d 90, 181 N.E.2d 445, 226 N.Y.S.2d 428 (1962) (agreement contained in will carried out after revocation of the will by the surviving widow and after her death).

s3 "[W] will, the agreement necessarily includes a promise not to breach the contract by revoking the will and failing to dispose of the property as agreed. . . . The rights of the parties to such an agreement depend upon the contract, and the revocation of the will or other breach of the contract does not prevent the intended devisee or legatee from enforcing the contractual obhigations. . . . The party who agrees to make a particular disposition of property by will pursuant to such a written agreement is estopped from making any disposition of the property different from that contemplated, and such estoppel cannot be avoided by his subsequent will in disregard of the terms of the contract. . . The basis of the estoppel lies in the acceptance of the benefits of the agreement by the promisor. ... In case of a breach the promisee has several remedies, such as action at law for damages, and equitable relief in the form of "quasi specific performance." 'Thompson v. Boyd, 32 Cal. Rptr. 513, 518-19 (Dist. Ct. App. 1963).

24 Janes v. Rogers, 224 Ark. 116, 271 S.W.2d 930 (1954); In re Estate of Shepherd, 130 So. $2 d 888$ (Fla. Dist. Ct. App. 1961); Matter of Estate of Isaacson, 77 Idaho 12, 285 P.2d 1061 (1955); Sellyei v. Lecso, 28 N.J. Super. 593, 101 A.2d 26 (Ch. 1953); In the Estate of Heys, [1914] P. 192. Contra, In the Matter of Estate of Edwards, 3 Ill. 2d. 116, 120 N.E.2d 10 (1954). The Edwards decision seems discredited, if not actually overruled by Jater Illinois cases. See In re Will of Lortz, 23 Ill. 2d 344, 178 N.E.2d 298 (1961); In re Estate of Baughman, 20 Ill. 2d 593, 170 N.E.2d 557 (1960). These cases emphasize that the probate court's function is only to determine the last will and testament of a decedent, not what sort of a will the decedent was under an obligation to make. It is axiomatic that a will may always be revoked, no matter how irrevocable the testator tries to make it. The claims that result from the revocation of a will which the testator should have left in force at his death are matters to be settled in Jaw and equity. Any resulting judgments may be levied 
Equity, however, may intervene and declare a constructive trust of the property in dispute and thereby effect a conveyance from the devisees of the survivor's will to the beneficiaries of the joint will. ${ }^{25}$ There is no reason why a legal action for damages will not lie against the estate, but this remedy is little used and may be inadequate where family personalty and real estate is involved. ${ }^{26}$

The rights of these contractual third party beneficiaries are not limited to correcting improper testamentary action by the surviving testator. Equity may also intervene where the survivor has made or is about to make an intervivos transfer of the property in such a manner as to defeat the plan inherent in the will. Where an intervivos transfer by the surviving testator has been completed, the conveyance may be set aside on the theory that the survivor was powerless to transfer title in such a transaction. ${ }^{27}$ Where the transfer is unexecuted, an injunction may issue on the ground that the survivor is estopped to deny his contractual obligations. ${ }^{28}$ In many cases involving interspousal joint and mutual wills, the courts allow the survivor to invade the property embodied by the contract for necessities and other good faith expenditures. ${ }^{20}$ Courts sanction this

upon the estate or the transferees of an improper will may be compelled to convey their bequests to the persons entitled to such property.

${ }^{25}$ Anderson v. Benson, 117 F. Supp. 765 (D. Neb. 1953); Brewer v. Simpson, 58 Cal. 2d 567, 349 P.2d 289, 2 Cal. Rptr. 609 (1960); Boner's Adm'x v. Chestnut's Ex'r, 317 S.W.2d 867 (Ky. 1958); Waters v. Harper, 69 Nev. 315, 250 P.2d 915 (1952); Minogue v. Lipman, 28 N.J. Super. 330, 100 A.2d 684 (App. Div. 1953); Scllyei v. Lesco, 28 N.J. Super. 593, 101 A.2d 26 (Ch. 1953); Rich v. Mottek, 11 N.Y.2d 90, 181 N.E.2d 445, 226 N.Y.S.2d 428 (1962); In the Matter of Estate of Young, 40 Wash. 2d 582, 244 P.2d 1165 (1952).

${ }^{26}$ Numerous cases hold that the beneficiary may obtain relief in law or equity. See, e.g., Brown v. Superior Court, 34 Cal. 2d 559, 563-64, 212 P.2d 878, 881 (1949); Curry v. Cotton, 356 Il. 538, 191 N.E. 307 (1934). Invariably the case seems to be brought for equitable rehef. Costigan, Constructive Trusts Based on Promises Made to Secure Bequests, Devises, or Intcstate Succession, 28 HARv. L. REv. 237, 250 (1915); Note, Joint or Mutual Wills, 61 HARv. L. REv. 675, 683 (1948). There seems to be no case that has denied equitable relicf because of the availability of an adequate remedy at law.

${ }^{27}$ Tontz v. Heath, 20 III. 2d 286, 170 N.E.2d 153 (1960); Eikmeier v. Eikmeicr, 174 Kan. 71, 254 P.2d 236 (1953); Glueck v. McMehen, 318 S.W.2d 371 (Mo. App. 1958). There is, however, strong indication that defenses such as laches may prevail against a beneficiary's claim. Tontz v. Heath, supra (adverse possession); Bonczkowski v. Kucharski, 13 Ill. 2d 443, 150 N.C.2d 144 (1958) (bona fide purchaser); Bell v. Pierschbacher, 245 Iowa 436, 62 N.W.2d 784 (1954) (bona fide purchaser).

${ }^{28}$ Brown v. Superior Court, 34 Cal. 2d 559, 212 P.2d 878 (1949); Thompson v. Boyd, 217 Cal. App. 2d 405, 32 Cal. Rptr. 513 (Dist. Ct. App. 1963); Scherb v. Nelson, 155 Cal. App. 2d 184, 317 P.2d 164 (Dist. Ct. App. 1957); Bonczkowski v. Kucharski, supra note 27; Campbell v. Dunkelberger, 172 Iowa 385, 390, 153 N.W. 56, 58 (1915). Cf. Chadwick v. Bristow, 146 Tex. 481, 208 S.W.2d 888 (1948).

${ }^{20}$ Brewer v. Simpson, 53 Cal. 2d 567, 589, 349 P.2d 289, 300, 2 Cal. Rptr. 609, 
invasion power because of the testator's presumed intention to make adequate provision for his surviving spouse..$^{30}$

Thus it would seem quite clear that the interest of the survivor in a contractual joint will situation is limited so that it cannot extend beyond his death or be conveyed in derogation of the plan manifested in the will. ${ }^{31}$ Conversely, it seems plain that a contractual joint will creates judicially cognizable interests in the third party beneficiaries.

\section{The Interests And the ReQuirements of the Code}

On the basis of the foregoing analysis, it would seem that the interest of a surviving spouse in a joint will situation does not satisfy the "non-terminability" test of section 2056 (b) (l). The ultimate beneficiaries of the will's distributive plan also seem to have future interests of a nature that would defeat the allowance of the deduction. ${ }^{32}$ However, even though the surviving spouse has only a limited interest and other parties do have rights in the same property, the value of the survivor's interest may still qualify for the deduction if the third parties' interests have not passed from the

620 (1960); In re Estate of Lenders, 247 Iowa 1205, 1215, 78 N.W.2d 536, 543 (1956).

If the terms of the will indicate that there are to be no restrictions on the survivor's power to deal with the property, a court will probably recognize that the survivor has an absolute fee simple, except for testamentary power. See Phinney v. Kay, 275 F.2d 776 (5th Cir. 1960); Murphy v. Slaton, 154 Tex. 35, 273, S.W.2d 588 (1954).

so Boner's Adm'x v. Chestnut's Ex'r, 3I7 S.W.2d 867 (Ky. 1958); Annot., 108 A.L.R. 867 (1937) and cases cited therein. If the property that the survivor is attempting to use for his own needs has always been his own separate property, the court will generally allow him to deal freely with such property in the absence of compelling evidence that the terms of the contract prohibit him from so disposing of that property. National Life Ins. Co. v. Watson, 141 Kan. 903, 44 P.2d 269 (1935); Rastetter v. Hoenninger, 214 N.Y. 66, 108 N.E. 210 (1915).

${ }^{31}$ In anaiyzing the case of Schildmeier v. United States, 171 F. Supp. 328 (S.D. Ind. 1959), which followed the Awtry holding and applied it to property held as tenancy by the entireties subject to a joint will contract, one commentator observed: "If one sets aside the Internal Revenue Code and analyzes the interest which the wife received in this case, it is obvious that a very appropriate word to characterize that interest would be 'terminable.' In view of the purpose of the marital deduction and the langnage of the provision, it appears highly unlikely that Congress intended that a decedent be allowed to exercise control over the wife's disposal of the property through contractual obligations and at the same time receive a marital deduction for his estate. . . . A more classic example of a terminable interest is difficult to conceive." 45 VA. L. REv. 1389, 1391 (1959).

32 The fact that these beneficiaries' interests might be cut off if the spouse invades for necessities does not destroy the existence of these interests for the purpose of the Code. The marital deduction section requires only that the interests may become possessory; it does not proscribe defeasibility. INT. REv. Cone of 1954, § 2056(b)(1)(B). 
decedent..$^{33}$ The Awtry case relies in part on the theory that all of the decedent's interest in the jointly held property had passed to the survivor by right of survivorship. The widow, by her own voluntary action, had incurred the contractual obligations that created the remainder-like interests in the relatives. Thus, the Eighth Circuit seems to reason, the interests of the third parties passed not from the decedent but rather from the survivor. ${ }^{34}$

This view, however, seems to ignore the fact that the interests were created, partially at least, at the behest of the decedent. In the Awtry case, the couple had no children and the ultimate disposition of the property was to be among the several nephews and nieces of the two spouses. The terms of the will were almost certainly a product of discussion between the husband and wife and represented their final agreement on the eventual devolution of the property. Further, prior to the death of the husband, he could have severed the joint tenancy with his wife ${ }^{35}$ and later devised his share to her

\footnotetext{
${ }^{33}$ INT. Rev. CODE of 1954, § 2056(b)(1)(A). See Comment, The Mysterious NonTerminable Terminable Interest: Reciprocal Wills, Inter-spousal Contracts, Joint Tenancies, and the Federal Estate Tax Marital Deduction, 55 Nw. U.L. REv. 727, 741 (1961), discussing two different views of the meaning of "passed from the decedent." Under one theory, passing would mean the relinquishment or surrender of the right of disposition by the decedent to another. The other viewpoint emphasizes the fact that interests once held by the decedent are, immediately following his death, held by another person. Under the latter view, the deceased's intent seems to mean less than the actual result. The estate tax regulations do not appear to adopt either view to the exclusion of the other. See Treas. Reg. $\$ 20.2056(\mathrm{c})(1)$ (1954). The Code itself specifies seven different methods by which the interest may pass. INT. Rev. CoDE of 1954, $\$ 2056$ (e). Two of these methods are devises or bequests and transfers by the decedent to the person at any time. It would seem that the interests of the third persons should meet the test of passing from the decedent either as a bequest or a transfer. The description in the will should make the eventual acquisition by the beneficiary $a$ bequest by the decedent. Also, it would seem that in reality, the decedent has transferred an interest in the property from himself to the beneficiary by leaving the joint contractual will as his own at his death.

Under both views presented in the note mentioned above, the result in a contractual joint will situation would scem to be the same. Under the "relinquishment" theory, the decedent has created rights in third parties by giving up his rights in the property through the terms of the contract. Under the second vicw concentrating on where the interests were and now are, the third parties now hold beneficial interests that were vested in the decedent before his death.

34 Estate of Awtry v. Commissioner, 221 F.2d 749, 759 (8th Cir. 1955). The court also pointed out that the interests of the third parties do not pass until the surviving spouse dies, leaving the joint will as his own. Such a view seems to disregard the fact that third parties now possess certain rights and powers that enable them to interfere with the survivor's handling of the property. Sec text accompanying note 2I-30 supra.

${ }^{35}$ The right of a joint tenant to sever the joint tenancy during his lifetime is virtually unquestioned. Annot., 64 A.L.R.2d 918 (1959). Two English cases hold that the mere execution of mutual contractual wills is so inconsistent with an inten.
} 
for life, remainder to the beneficiaries of his selection. Such an interest acquired by the wife would not have qualified for the deduction. ${ }^{36}$ When the husband died leaving the joint will as his own, he imposed a similar result not only on one-half of the jointly held property, but on all of it. ${ }^{37}$ It is submitted, therefore, that at least

tion by the tenants to continue to hold jointly that the tenancy is converted to a tenancy in common. In the Estate of Heys, [1914] P. 192 (husband and wife); In re -Wilford's Estate, 11 Ch. D. 267 (1879) (two sisters). This view was followed in a Kansas case, Berry v. Estate of Berry, 168 Kan. 253, 212 P.2d 283 (1949) (husband and wife), which was relied upon by the Commissioner in the Spicer case. $217 \mathrm{~F}$. Supp. at 50. However, it has also been held that a joint will does not act to terminate a joint tenancy. Jerzyk v. Marciniak, 10 Ill. 2d 529, 140 N.E.2d 692 (1957). But the terms of a joint will contract are binding upon jointly held property. Bonczkowski v. Kucharski, 13 Ill. 2d 443, 150 N.E.2d 144 (1958). Cf. Tiemann v. Kampmeier, 252 Iowa 587, 107 N.W.2d 689 (1961).

The court in the McLean case was faced with a situation where the property was held by the entireties. While such a tenancy cannot be severed by the individual action of one of the tenants, courts that have considered the question have held that it may be severed by mutual consent. Runco v. Ostroski, 361 Pa. 593, 65 A.2d 399 (1949); Michalski v. Kruszewski, 330 Pa. 62, 198 Atl. 673 (1938). Because of the particular characteristics of tenancy by the entireties, courts might be reluctant to infer that it had been severed by a joint will, although the execution of such an instrument would be dealing with the incidents of such a tenancy that it might indicate that the parties no longer considered it such a tenancy. Of course, in executing a joint will, the parties probably never give any thought to the question of whether they are severing any type of tenancy.

The termination of a tenancy by the entireties or an inter-spousal joint tenancy with right of survivorship may raise gift tax complications. See INT. REv. CODE of $1954, \S 2515(\mathrm{~b})$; Treas. Reg. § 25.2515 (1954).

${ }^{30}$ INT. REv. CoDE of 1954, $\$ 2056(\mathrm{~b})(1)$. The estate tax regulations give the following example: " $H$ (the decedent) devised real property to $W$ (his surviving wife) for life, with remainder to $A$ and his heirs. The interest which passed from $H$ to $W$ is a nondeductible interest since it will terminate upon her death and $A$ (or his heirs or assigns) will thereafter possess or enjoy the property." Treas. Reg. § 20.2056(b)-1(g) (1954).

${ }^{37}$ Precisely when the beneficiaries' interests under a joint and mutual will originate depends upon the type of contract theory adopted in evaluating the consequences of the will. If the court finds a bilateral contract effective from the moment of agreement, then the interests would rise before the death of the first testator. Doyle v. Fischer, 183 Wis. 599, 198 N.W. 763 (1924). Under the Code, this would not affect the fact that an interest passed froin the decedent. One of the methods specified for "passing" is a transfer to the third person by the decedent at any time. INT. REv. CODE OF 1954, $\$ 2056$ (e)(4).

Most courts, however, incline toward the view that a unilateral contract is involved, stating that the contract becomes binding on the survivor only after the death of the first testator, and then only if the decedent has not previously revoked the will. While so holding, the courts often state, obiter dictum, that the first testator to die has no right to secretly revoke the will before his death. Courts also often state that the survivor must accept the benefits of the will in order to be bound by its terms. See, e.g., Levis v. Hammond, 251 Iowa 567, 100 N.W.2d 638 (1960); Kirk v. Beard, 162 Tex. 144, 345 S.W.2d 267 (1961). See generally 41 IowA L. REv. 462, 464-66 (1956). But see Estate of Charles Elson, 28 T.C. 442 (1957). In the Elson case, the Tax Court held that the widow had no right to renounce the joint will and refuse a life estate in all of the decedent's property. The widow had 
part of the third persons' beneficial interests did pass from the decedent. The court, however, allowed the deduction for the full value of the joint tenancy property.

The Commissioner maintained that the deduction should not be allowed for any part of the joint tenancy property. This position seems logical in light of section 2040 of the Code and the economic realities of the transaction. For purposes of determining the gross estate, section 2040 provides that the whole value of any joint tenancy property is included in the estate of the decedent if he supplied the whole consideration for the purchase of such property.88 In the ordinary situation where husband and wife hold as joint tenants, the husband's earnings provide that consideration. ${ }^{30}$ In such a situation, the whole value of the jointly held property would usually qualify for the deduction since the surviving widow receives the full interest in the property. ${ }^{40}$ The widow in the Awtry case, however, did not in economic reality receive the type of absolute interest that section 2056 (a) contemplates. By virtue of the contract inferred from the joint will, she was obligated to allow the property to pass at her death according to the terms previously agreed upon. ${ }^{41}$

renounced and received a statutory one-third interest in fee-simple of the decedent's property. The sole purpose had been to take advantage of the marital deduction.

Whether or not an interest is terminable is determined at the date of decedent's death. Jackson v. United States, 32 U.S.L. WEEK 4222, at 4223 (March 23, 1964); S. REP. No. 1013, 80th Cong., 2d Sess. pt. II, at 10 (1948). If the survivor has an absolute right to elect a deductible interest and does so elect, then that interest will qualify for the deduction. Ballantine v. Tomlinson, 293 F.2d 311 (5th Cir, 1961); Estate of Shedd v. Commissioner, 237 F.2d 345 (9th Cir. 1956), cert. denied, 352 U.S. 1024 (1957); Treas. Reg. $\S 20.2056(\mathrm{e})-3$ (1954). The interest of the third person may have passed to him at any time. INr. REv. CoDE of 1954, $\S 2056(\mathrm{~b})(1)(\mathrm{A})$, (c)(4); Treas. Reg. $\$ 20.2056$ (b)-I (e) (1) (1954).

${ }^{38}$ INT. REV. CODE OF 1954, § 2040.

39 This was the case in both Awtry and McLean. Estate of Awtry v. Commissioner, 221 F.2d 749, 753 (8th Cir. 1955); McLean v. United States, 224 F. Supp. 726, 727 (E.D. Mich. 1963).

${ }^{10}$ S. Rep. No. 1013, 80th Cong. 2d Sess., pt. I, at 27 (1948). See Treas. Reg. \$\$ 20.2056(b)-1, (c)-1(a)(1), (c)-2(a). The amount of the deduction, of course, would still be limited to fifty per cent of the adjusted gross estate. INT. REv. ConE of 1954, $\S 2056(c)$.

11 The Eighth Circuit assumed that Mrs. Awtry was bound contractually by the terms of the will. 221 F.2d at 757-59. The court today probably would not have to make such an assumption. The will itself apparently contained no reference to any agreement to keep the will in force. 22 T.C. at 92. The circumstances in Awtry were such that a contractual joint will might well have been an appropriate method for the couple to accomplislı their wishes. Nevertheless, courts are reluctant to presume that a joint will has been executed pursuant to an agreement between the testators not to revoke the instrument. Unless the contraet appears on the face of the will itself, or can be proved by clear, cogent, and compelling evidence, the 
Since the survivor's interest in the property does not match the requirements of section 2056, it would seem probable that Congress did not intend that such an interest should qualify for the deduction. ${ }^{42}$

contract will not be enforced and the survivor will be free to deal with the property as he sees fit. Sparks, Contracts to MAKe Wilis 24, 25 (1956); Ireland v. Jacobs, 114 Colo. 168, 163 P.2d 203 (1945); Keith v. Culp, III So. 2d 278 (Fla. 1959); Lindley v. Lindley, 67 N.M. 434, 356 P.2d 455 (1960); Oursler v. Armstrong, 10 N.Y.2d 385, 179 N.E.2d 489, 223 N.Y.S.2d 447 (1961); Lyons v. Luster, 359 P.2d 567 (Okla. I960); Williams v. Rhode Island Hosp. Trust Co., 88 R.I. 23, 143 A.2d 324 (1958); Ellison v. Watts, 227 S.C. 411, 88 S.E.2d 351 (1955). Contra, Frazier v. Patterson, 243 Ill. 80, 90 N.E. 216 (1909); Doyle v. Fischer, 183 Wis. 599, 198 N.W. 763 (1924). The Iowa courts, which would liave settled any of the contractual problems arising in the Awtry situation, were once quite willing to imply a contract from interspousal joint and mutual wills under almost any circumstances. Jennings v. McKeen, 245 Iowa 1206, 65 N.W.2d 207 (1954) (relied upon by the Commissioner and accepted by the court in Awtry); Gulver v. Hess, 234 Iowa 877, 14 N.W.2d 692 (1944); Campbell v. Dunkelberger, 172 Iowa 385, 153 N.W. 56 (1915); Baker v. Syfritt, 147 Iowa 49, 125 N.W. 998 (1910). The Iowa Supreme Court abandoned this viewpoint in 1956, noting that the prevailing rule in this country was that no contract could be implied from the mere execution of a joint will. In re Estate of Lenders, 247 Iowa 1205, 78 N.W.2d 536 (1956). The Lenders case has since been followed several times. Father Flanagan's Boys' Home v. Turpin, 252 Iowa 603, 106 N.W.2d 637 (1961); Barron v. Pigman, 250 Iowa 968, 95 N.W.2d 726 (1959); Allinson v. Horn, 249 Iowa 1351, 92 N.W.2d 645 (1959); In re Estate of Ramthun, 249 Iowa 790, 89 N.W.2d 337 (1958). In the Father Flanagan's Boys' Home case, the court held that the evidence did not support the finding of a contract despite the joint will. The survivor was therefore free to dispose of the property intervivos to charity. A previous agreement between the surviving widow and the Commissioner of Internal Revenue that the interest which she received under the joint will was not adequate to qualify for the marital deduction did not estop the widow from asserting that there was no restriction upon her right to convey in the immediate action. 106 N.W.2d at 642.

${ }^{2}$ One of the main purposes of the marital deduction is to allow property to be subject to the estate tax only once in a generation, but not to allow it to escape such taxation in passing to a new generation. United States v. Stapf, 375 U.S. II8, 128 (1963). Thus interests qualifying for the marital deduction will ordinarily be included in the survivor's estate. See note 8 supra.

Two cases lave dealt with the includibility in the survivor's estate of interests taken subject to a contract inherent in a joint will. In Olson v. Reisimer, $271 \mathrm{~F} .2 \mathrm{~d}$ 623 (7th Cir. 1959), the Court of Appeals reversed a district court decision that the survivor's interest was not includible in lis estate. The property liad been owned by the first decedent and the survivor as joint tenants. The will provided that it should after the death of the first spouse be held by the survivor as a life estate. The survivor, however, had contributed part of the consideration for the purchase of the joint tenancy assets. The Seventh Circuit ruled that the one-half interest whicl the survivor had passed in remainder to the named beneficiary should be included in the survivor's estate. In Phinney v. Kay, 275 F.2d 776 (5tl Cir. 1960), the court reversed another district court decision favoring the taxpayer. The survivor's representatives argued that the survivor did not liave a sufficient power of appointment for the property to be included in the estate. In analyzing the applicable state law, the Fifth Circuit decided that there were in fact no limitations on the survivor's control over the property.

Both of the above cases seem properly decided, especially if the Fifth Circuit properly analyzed Texas law. However, if state law did impose restrictions on the survivor, the power of appointment miglit be of a type that would preclude the 
Thus it would seem that the ordinary bequest or devise under a contractual joint or mutual will should not qualify for the marital deduction under section 2056 (b) (l). The surviving spouse's interest is limited and "terminable"; third parties do acquire rights and interests in the same property; those interests have come from the decedent in the case of separate property; and those interests have come, in part at least, from the decedent in the case of jointly held property.

The argument that the interest qualifies for the deduction as a life estate coupled with a power of appointment seems no stronger than that for qualifying it under section 2056 (b) (1). The Code requires that the power be exercisable by the surviving spouse in his sole discretion. ${ }^{43}$ The rights of the beneficiaries as discussed above ${ }^{44}$ would seem to interfere with any absolute control by the survivor over the property. ${ }^{45}$ The surviving spouse may, as indicated previously, ${ }^{46}$ have the power to invade for necessities, if the power is not exercised to defraud the beneficiaries of the joint will. In interpreting the interests acquired by spouses in other than joint will situations, however, appellate courts have been uniform in demanding that the survivor's power not be limited by such factors as reasonableness or good faith. ${ }^{47}$ Allowing a decedent to escape the effects of

property from being included in the survivor's estate. INT. REv. CODE OF 1954, \$ 2041(b)(1)(A). See also note 47 infra.

13 INT. REv. CODE OF 1954, § 2056(b)(5).

\$S See text accompanying notes 21-28 supra.

15 The estate tax regulations do not deal specifically with a joint will situation, but the following treats generally contractual restrictions upon the surviving spouse. "The power of the surviving spouse must be a power to appoint the . . . interest ... . as unqualified owner... that is, in effect, to dispose of it to whomsoever she pleases. Thus, if the decedent devised property to a son and the surviving spouse as joint tenants with right of survivorship and under local law the surviving spouse has a power of severance exercisable without the consent of the other joint tenant, and by exercising this power could acquire a one-half interest in the property as a tenant in common, her power of severance will satisfy the condition . . . that she have a power of appointment in favor of herself or her estate. However, if the surviving spouse entered into a binding agreement with the decedent to exercise the power only in favor of their issue, that condition is not met." Treas. Reg. $\$ 20.2056(\mathrm{~b}) \cdot 5(\mathrm{~g})(2)$ (1954). (Emphasis added.)

10 See text accompanying notes 29.30 supra.

- In Estate of Peyton v. Commissioner, 323 F.2d 438 (8th Cir. 1963), the survivor could invade the estate only if "necessary in her judgment for comfortable mainte. nance and support" of herself and the children. The court found these limitations restricted the power and accordingly denied the deduction. In United States v. Lincoln Rochester Trust Co., 297 F.2d 891 (2d Cir.), cert. denied, 369 U.S. 887 (1962), New York law required that any power of appointment be exercised in good faith and upon honest judgment. The circuit court found that the power would therefore not be exercisable in all events and accordingly did not allow the deduction. To 
these holdings by the use of a contractual rather than an ordinary testament seems to open an unintended loophole in estate taxation. It also seems to exalt form over substance in application of the tax laws. The results of the cases therefore seem unjustifiable under any reasonable statutory construction of the marital deduction provisions of the Code. ${ }^{48}$

\section{The Gases and Congressional. Intent}

In enacting the marital deduction provisions, Congress intended to allow residents of common law property states to bequeath to their surviving spouses the equivalent of a community property share of their accumulated wealth without incurring a greater tax burden than would be imposed on the estates of residents of community property states. ${ }^{49}$ It might be contended that, since the interest acquired by the surviving spouse under a joint and mutual will does not necessarily approximate the ordinary community property

the same effect, see Piatt v. Gray, 321 F.2d 79 (6th Cir. 1963) (discussed at note 6, supra); Estate of Semmes v. Commissioner, 288 F.2d 664 (6th Cir. 1961) (power to encroach for survivor's benefit held not broad enough); Commissioner v. Estate of Elhis, 252 F.2d 109 (3d Cir. 1958) (Pennsylvania law construed in conformance with that of New York in Lincoln Rochester case, supra); Annot., 90 A.L.R.2d 414, 437-43 (1963). But see Hoffman v. McGiness, 277 F.2d 598 (3d Cir. 1960) (Pennsylvania law as determined in Ellis case, supra, overcome by use of words "as she desires").

\&s "[T] $]$ he device of the marital deduction which Congress chose to achieve uniformity was knowingly hedged with limitations, including the terminable interest rule. These provisions may be imperfect devices to achieve the desired end, but they are the means which Congress chose. To the extent it was thought desirable to modify the rigors of the terminable-interest rule, exceptions to the rule were written into the Code. Courts should hesitate to provide still another exception by straying so far from the statutory language as to allow a marital deduction for the widow's allowance provided by the California statute." Jackson v. United States, 32 U.S.L. WEER 4222, 4224 (U.S. March 23, 1964). (Emphasis added.)

Of course, if the joint will has not been executed pursuant to a contract making its terms binding upon the survivor, he would receive the equivalent of a fee simple and the estate should accordingly be allowed the deduction. The estate would also be entitled to the marital deduction if the terms of the contract were such that the survivor had a complete power over the property, including the power to dispose of it in contravention of the plan set out in the will. See Estate of James Mead Vermilya, 41 T.C. No. 26 (Nov. 20, 1963). Such a contract is possible and its, terms would be enforced. Phinney v. Kay, 275 F.2d 776 (5th Cir. 1960). But a person using a joint will in order to insure that beneficiaries of his selection will eventually get part of his wealth is probably not consenting to such an agreement. The decedent would not want the surviving spouse to have the power to give the property away to such persons as a future spouse of that survivor.

«o United States v. Stapf, 375 U.S. 118, 128 (1963); Gelb v. Commissioner, 298 F.2d 544 (2d Cir. 1962). 
interest, Congress did not intend to allow that portion of the estate to be exempt from taxation. ${ }^{50}$

Congress' prime motive, however, in devising the marital deduction was the elimination of tax discrimination between the two types of property jurisdictions. ${ }^{51}$ A married couple in a community property state is free to subject its community property to the terms and restrictions of a joint will.52 In such a case, the share that belongs absolutely to the survivor by virtue of community property law would not be subject to taxation in the estate of the first spouse to die.53 Thus the surviving spouse in a community property jurisdiction would receive one-half of such property free of the tax, and, in addition, the decedent's share of the community property reduced by the estate's expenses and taxes. From this source, the survivor may draw income and provide for necessities during his lifetime. In a common law jurisdiction, the survivor's interest in the estate might turn out to be considerably smaller if all the property is included in the taxable estate of the first spouse to die. If section 2056

${ }^{\circ}$ To qualify for the deduction, the administrator or executor must show that the devise clearly comes within the terms of the statute. McGehee v. Commissioner, 260 F.2d 818, 822 (5th Cir. 1958). Cf. United States v. Denison, 318 F.2d 819 (5th Cir. 1963). However, since the marital deduction provisions were enacted with the intent to eliminate tax discrimination, some courts hold that $\S 2056$ should be liberally construed. United States v. Crosby, 257 F.2d 515, 518 (5th Gir. 1958); Estate of Awtry v. Commissioner, 221 F.2d 749, 759 (8th Cir. 1955). But see Jackson v. United States, 32 U.S.L. WeEK 4222 (U.S. March 23, 1964).

E2 S. REP. No. 1013, 80th Cong., 2d Sess., pt. I, at 3 (1948). Congress made an attempt in 1942 to equalize the tax treatment between estates in the two types of property jurisdictions. It was provided that all the community property which had been produced by the decedent's efforts would be included in his estate. Int. Rev. Code of 1939, $\$ 811$ (e) (2), as amended, ch. 619, 56 Stat. 942 (1942), repealed, ch. 168, 62 Stat. 116 (1948). This was designed to treat community property similarly to a joint tenancy, See INT. REv. CODE OF 1954, $\S 2040$. However, the interest of the spouse in a community property state was taxed in his estate even if he had contributed no effort to its acquisition, since that spouse had a testamentary power over that share. This proved to be highly discriminatory against residents of community property states, but the statute was nevertheless held to be constitutional. Fernandez v. Weiner, 326 U.S. 340 (1945); United States v. Rompel, 326 U.S. 367 (1945). The 1948 Revenue Act, which created the marital deduction, repealed the 1942 amend. ments and tried to equalize the estate tax treatment between the jurisdictions by extending to decedents in common law states the same tax advantages enjoyed by community property estate taxpayers before the 1942 amendments. 62 Stat. 110 (1948); S. REP. No. 1013, 80th Cong., 2d Sess., pt. I, at 26, 27 (1948). See generally LowNDES \& KRAMER 349-52.

${ }^{62}$ Brewer v. Simpson, 53 Cal. 2d 567, 585, 349 P.2d 289, 297, 2 Cal. Rptr, 609, 617 (1960); Chadwick v. Bristow, 146 Tex. 481, 208 S.W.2d 888 (1948); Wagnon v. Wagnon, 16 S.W.2d 366, 369 (Tex. Civ. App. 1929). Cf. Odell v. Odell, 306 S.W.2d 914, 917 (Tex. Civ. App. 1957).

${ }^{58}$ INT. Rev. Code of 1954, $\S 2033$; S. REP. No. 1013, 80th Cong., 2d Sess., pt. I, at 28 (1948). 
were strictly applied, not only would the whole estate be taxed, but, quite conceivably, the estate would be subject to a higher rate of tax than the estate of a corresponding decedent in a community property jurisdiction. ${ }^{54}$ In light of this possibility, the Awtry result may be just and equitable, but only at the heavy price of dubious statutory construction.

"5 $\mathrm{A}$ surviving spouse in a community property jurisdiction, who is bound by a joint will contract after the decedent's death, will receive one of the community property shares reduced by taxation. The other share will not be included in the decedent's estate because it has always been viewed as a vested right of property in the survivor. Accordingly, that share will not be reduced by taxation upon the death of the first spouse. However, in a common law property state, where the decedent has accumulated all the property and devised it to his surviving spouse subject to a joint will contract, all of the property will be included in his estate. If a court found that the property interest received by the survivor in the common law jurisdiction were inadequate to qualify for the marital deduction, then all of the decedent's property would be included in the taxable estate and be subjected to the tax.

The resultant discrimination might best be viewed by an example in actual figures. Suppose that two decedents, one residing in New York and the other in Texas for all their lives, have managed to accumulate $\$ 160,000$ during their marriages, each decedent having supplied all the effort to obtain the savings. Assume that no other property has come to the decedent from any other source. In Texas, where the property would be viewed as community, the decedent's gross estate will amount to $\$ 80,000$, his share of the community. If there are no other deductions for the estate other than the specific exemption, the decedent from Texas will leave a taxable estate of $\$ 20,000$. The tax due will amount to $\$ 1,600$. If all of the estate passes to the surviving spouse subject to the joint will contract, the survivor will have the $\$ 78,400$ received from the decedent in addition to his own $\$ 80,000$ community property share from which to draw income during his life. The New York decedent, however, will have the entire $\$ 160,000$ included in his gross estate. If the property passes to the surviving spouse for life by terms of the joint will, then no marital deduction will be allowed if the statute is literally followed. If it is again assumed that the specific exemption is the only amount to be deducted from the gross estate, the taxable estate will be $\$ 100,000$. On this amount, the federal tax will be $\$ 20,700$. The surviving spouse in New York will thereby receive only $\$ 139,300$ from which to draw income during his life and to invade for necessities in comparison to the $\$ 158,400$ received by his Texas counterpart. Also, if the interests created in the surviving spouses are insufficient to be included in the survivor's estate, the amount passed on to the next generation will also be considerably larger in the community property state.

A recent decision of the Supreme Court may destroy some possible ramifications of this example. If, in Texas, the decedent had also possessed some separate property, a question as to the allowability of a marital deduction may arise. But if the surviving spouse suffers a diminution in the value of his community property share in order to receive some of the decedent's property which ordinarily would qualify for the deduction, the possible deduction will be reduced by the loss in value of the survivor's share. United States v. Stapf, 375 U.S. 118 (1963). In that case, the value of what the survivor received from the decedent was less than what he was obliged to convey away in order to receive a portion of the estate. What the surviving widow did receive would ordinarily have qualified for the deduction. But since he received it subject to the obligation, the Court held that the survivor had in reality received nothing and consequently denied any deduction. Id. at 128. See INr. REv. CODE OF $1954, \$ 2056$ (b) (4) (B). 


\section{CONGLUSION}

Much criticism has been leveled at the use of contractual joint wills. ${ }^{55}$ The most cogent objection would seem to be their dubious tax standing. No circuit court has contradicted the Awtry result, but the Tax Court adheres to its original opinion in that case. ${ }^{67}$ Even a definitive Supreme Court decision might prove of little value since it is well established that state law determines the nature of interests created by a decedent, with federal tax law being applied

E Sparks, Contracts to Make Wills 30 (1956); Fingar, Joint, Mutual and Recipro. cal Wills, 94 TRUSTs \& EsTATES 782 (1955); Owen, What Every Lawyer Should Know about Joint and Mutual Wills, 42 IL.. B.J. 684 (1954). But see Durand, Planning Lessons from Marital Deduction Litigation, 101 Trusts \& Estates 8, 10 (1962); Highley, A Case for a Joint Will, 32 PA. B.A.Q. 291 (1961). Both of the last two authors mentioned concede that a joint will might sometimes be useful, but not if executed pursuant to a contract.

${ }^{5}$ But see Estate of Gust Marion Peterson, 23 T.C. 1020 (1955), rev'd on other grounds, 229 F.2d 741 (8th Cir. 1955). In the Peterson case, the Tax Court followed its Awtry holding and denied the deduction, which resulted in an additional estate tax of $\$ 59,053.32$. 23 T.C. at 1020 . The case was appealed to the Eighth Circuit, which had just decided the Awtry case, Peterson seemed to be on all fours with Awtry, except for the states involved. (Peterson was a Nebraska resident, Awtry a Iowa resident). Instead of reversing on the merits, the Court of Appeals remanded on a minor point as to payment of a $\$ 467.72$ deficiency. 229 F.2d at 741 . See also Lindsey v. United States, 167 F. Supp. 136 (D. Md. 1958). In that case, the surviving wife had contracted with the decedent before his death to accept the terms of his will setting up a trust for her benefit for life, remainder to others. The widow also agreed to convey to the trustces property acquired by her at the decedent's death by virtue of having held it as a tenant by the entireties with her husband before his death. Since the widow took the property subject to the obligation to convey it away, the district court refused to qualify the value of the property held by the entireties for the deduction. The Awtry case was distinguished by the fact that the beneficiaries' interests arose under Mrs. Awtry's will and not at Mr. Awtry's death.

The Awtry holding was followed in Schildmeier v. United States, 171 F. Supp. 328 (S.D. Ind. 1959) (discussed, note 31 supra) and Newman v. United States, 176 F. Supp. 364 (S.D. Ill. 1959). In the Newman case, the property passing under the will itself as the separate property of the decedent was qualified for the deduction because it was devised as a fee simple absolute to the survivor. The mutual wills involved, however, contained a reference to an agreement that they should be irrevocable.

57 The Tax Court relied on its Awtry position for its hoiding in the Peterson casc, note 56 supra. Both cases were distinguished in Estate of James Mead Vermilya, 41 T.C. No. 26 (Nov. 20, 1963). The Vermilya case can be read, however, as an indication that the Tax Court may adopt the Eighth Circuit's approach to joint wills. The case was decided under Minnesota law, which contained practicaliy no case authority as to the effects of a joint will. The will contained no reference to a contract. Were Minnesota to adopt the inajority view, absent other evidence there would have been no contract for a court to enforce. See note 41 supra. However, the Tax Court implied a contract to devise whatever property remained undisposed of at the surviving spouse's death. This type of contract might enable the court to qualify the interest under $\S 2056$ (b) (5) unless some good faith limitations could be imposed. The Tax Court, however, held that the survivor received an absolute fee simple interest for her lifetime. This was sufficient for qualification, in the Tax Court's view, under $\S 2056$ (b) (1). 
to those interests as so determined. ${ }^{58}$ Since state laws are not uniform with regard to joint wills, it is quite likely that each case will require an ad hoc decision.

${ }^{68}$ Helvering v. Stuart, 317 U.S. 154, 161 (1942); Morgan v. Commissioner, 309 U.S. 78, 80 (1940); United States v. Mappes, 318 F.2d 508, 511 (10th Cir. 1963); Estate of Awtry v. Commissioner, 221 F.2d 749, 753 (8th Cir. 1955). 